\title{
China in Global Governance: Ideology, Theory, and Instrumentation
}

Evgeny N. Grachikov

\author{
Evgeny N. Grachikov, Ph.D. in Political Science \\ Peoples' Friendship University of Russia, Moscow \\ Department of Theory and History of International Relations \\ Associate Professor \\ ORCID: 0000-0003-3153-9650 \\ SPIN-RSCI: $5243-2580$ \\ E-mail: grachikov-en@rudn.ru \\ Tel: +7 495-952-0629 \\ Address: 6 Miklukho-Maklaya Str., Moscow 117198, Russia
}

This article was prepared as part of research project \#20-514-930003 “Russia and China in the Global Political Space: Harmonization of National Interests in Global Governance" supported by the Russian Foundation for Basic Research and the Chinese Academy of Social Sciences.

DOI: $10.31278 / 1810-6374-2020-18-4-132-153$

\begin{abstract}
Over the past few years, the global political landscape has changed dramatically. Trump's aggressive foreign policy has broken the precarious balance between the centers of world politics established in the past two decades. The U.S. trade war with China and accusations of creating COVID-19 have added a significant imbalance to the distribution of power in global governance.

The current political global space is characterized by a tough struggle between the main centers of power for spheres of influence in macro regions, global power and redistribution of world incomes. In fact, it is a struggle for
\end{abstract}


competition in setting the principles, norms and models of the future world order. Most of the developing countries in Asia, Africa, and Latin America are distancing themselves from the West on many international issues, and advocating the creation of national concepts of world order (in "non-West," "post-West," "outside the West" formats), which would take into account the political and cultural traditions of their countries, and the specific experience of their interaction with neighboring states and the world as a whole. Thus, the competition in global governance between the United States and China is for a new global order, including influence on the vast Global South.

This article offers an analysis of China's strategy of global governance and Chinese academic discourse on this issue. The paper also examines China's instrumentation for formatting its own structure of global governance and forms of strategic rivalry with the United States.

Keywords: global governance, strategic rivalry, world order, international regime, norms, rules, COVID-19, China, the U.S.

\section{CHINESE ACADEMIC DISCOURSE ON GLOBAL GOVERNANCE}

There are more and more researchers in China who purposefully explore various types of global governance and related international affairs. On June 20,2013, the first all-China scientific conference on global governance was held. It was attended by over 60 scholars from more than 20 universities, research institutes and leading journals writing about international relations (Yang Hao, 2013, pp.63- 64). The first "Introduction to International Organizations" under the editorship of Zhang Lihua came out in 2015 (Zhang Lihua, 2015), followed in 2016 by "China and Globalization: a View from Beijing and Moscow," edited by Zhang Yuyan (Zhang Yuyan, 2016).

In China, global governance is understood as a new type of principles, mechanisms, methods, and activities focused on the values professed by holism and on the common interests of humankind, whereby various actors, using equal dialogue, negotiations and cooperation for managing the public affairs of humankind, jointly respond to global changes and global problems. Global governance is essentially a transition from governmental to non-governmental, from the state to society, from 
territorial politics to non-territorial politics, from forced governance to equal, advisory, voluntary and network-based governance, which represents a special type of political power. Global governance has a major impact on international relations: it breaks the state-centric system and model of international relations and allows humanity to solve more complex international issues; it encourages people to participate in the public affairs of humankind and facilitates the democratization of international relations; it promotes dialogue, cooperation, coordination, and political transformation of conflicts in international relations; and it helps develop international relations in a just and reasonable manner (Huang Rihan and Yao Yufei, 2013, p.235).

China is actively forming a global network of partnerships, which includes more than 100 countries in five macro regions around the world (Grachikov, 2019a, pp.83-93), applying its own regulatory requirements to other countries (Grachikov, 2019b, pp.154-173), and actively using Western classical approaches to building relations with the United States and the world community as a whole (Grachikov, 2019c, pp.187-200).

The Russian academic community has adopted the view that global governance is a system of institutions, principles, political and legal norms, and behavioral standards that determine the regulation of transnational and global problems through the interaction of states. The most comprehensive collection of Russian academic views on this issue can be found in the "Global Management: Opportunities and Risks" (Global Governance, 2015).

Some Chinese researchers name the G20 as an important platform for global governance, emphasizing China's special role in this forum. For example, Zhang Lin has said that the G20 "is currently the main forum for international economic cooperation, which plays an important role in promoting global economic development and strengthening policy coordination" (Zhang, 2016). This is the first global governance mechanism in which China participates as a founding country and a key member. The G20 is short for the Group of Twenty. The historical condition for the Group's creation was that the G8 did not have sufficient representation to address global economic 
issues. Like the G8, the G20 is an informal forum that enables major countries to engage in dialogue within the Bretton Woods system. The goal of the G20 is to facilitate the modernization of the international financial system, to create a broad basis for discussion and consultation on issues of mutual interest, to seek cooperation, and to promote stability and sustainable growth of the world economy. Since the 2008 financial crisis, G20 has been focused on rebuilding the global economy. Zhang Lin emphasizes that reform and reorganization of the international financial system consisting of the IMF, the WTO, the World Bank Group, and the G8 is already inevitable, because the measures they take to overcome crises do not work (Zhang, 2016).

Zou Yabao and Wang Kai call the institutionalization of the G20 an urgent need of China, because the Group has already gone a long way from addressing international economic issues to dealing with international relations and global political governance. The institutionalization of the G20 would be a good opportunity for China to participate more profoundly in global economic governance and promote reform of the international financial order (Zou and Wang, 2011, p.34).

There are two groups in the world that contribute to economic development: the first one consists of developed countries, and the second one is made up of developing countries: the G7 and BRICS, respectively. The G20 essentially integrates these two groups, whereby China finds it very important and seeks to promote its development (Jin and Gu, 2016, p.8). In his study, Pang Zhongying has raised the important issue of global governance deficit. In his opinion, this is a serious problem facing the world community. Pang defines global governance as the management of problems on a global scale and at the global level (Pang, 2016, p.3).

\section{INDEPENDENT VARIABLES OF CHINA'S DIPLOMACY IN GLOBAL GOVERNANCE}

Diplomatic strategies. The conceptualization of China's foreign policy as diplomatic strategies, which reflect the traditional political philosophy and the practice of foreign relations employed in ancient 
China, originated during the Warring States period in the form of stratagems (and then strategies) (Grachikov, 2015, pp.34-46). Diplomatic strategies represent a chartered course and a strategy of protecting national interests of the country, carried out in the process of interstate interaction at a certain time, depending on national conditions. They include political, economic, cultural, ethnic, and other survival strategies related to the country's development (Diplomatic Strategies, 2020). Diplomatic strategies are a common idea, comprehensive calculation and a universal plan of diplomatic action by means of diplomacy as an independent agent (Jin, 1999, pp.97-90). The entire history of China's diplomacy is a natural process of constantly changing diplomatic strategies. China's foreign policy practice until 1978 showed that short-term diplomatic strategies covering about ten years (for example, the strategy of "Leaning to One Side") are an integral part of long-term strategies spanning thirty years or more (for example, the strategy of "Joining Alliances," and now the "Chinese Dream" or "Two Centennial Goals"), which, in turn, are only a "small part" of China's Grand Strategy. China’s Grand Strategy, as defined by Yuan Pan, President of the Chinese Institutes of Contemporary International Relations, refers to "the embodiment of ideals and policies that represent the provision of long-term leadership for the future of a country that goes beyond individual organizations or political parties and eliminates the demarcation line between domestic and international affairs" (Yuan, 2013, p.3). According to Ye Zicheng, the Grand Strategy is a huge strategic system that includes a number of interconnected and various strategies integrating the long-term momentous state goal of transforming China into a world power (Ye, 2003, p.2).

China's national interests include the protection of sovereignty and territorial integrity, the maintenance of internal stability, economic growth and the achievement of China's status as a great power. These interests have remained fairly consistent and unchanged for decades (Yan, 1996; Hong, 1999). With the growth of economic power and export opportunities, as $\mathrm{Xu}$ Jia observes, the national interests of China 
began to slowly expand beyond its borders (Xu, 2006, p.19). When analyzing the national interests of China, Ye Xiaodi used the approach of neoclassical realism by taking power structure as an independent variable and China's strategic orientation and the reaction of adjacent/ peripheral/neighboring countries as intermediate variables. Based on the relationship between these three variables in the shift/transit of China's national interests, he classified them as "defensive national interests," "constructive national interests," and "competitive core interests," extending their application from domestic and regional to interregional and international levels. Ye Xiaodi believes that China's national interests have changed over the past forty years as follows: 1980-1990 was a period of bipolarity and defensive national interest; in 1991-2010, they gave way to unipolarity and constructive national interest; in 2011-2017, China opted for multipolarity and competitive core interests (Ye, 2003, pp.76-115). China’s foreign policy/diplomacy changed accordingly from that of "a participant" to that of "a leader" of the world political system.

\section{China's relations with two great powers, the USSR/Russian Federation} and the United States, have always had a significant impact on the development of its specific diplomatic strategies ("Lean to One Side," "One Line") (Ye, 2003, p.2), due to ancient Chinese concepts of using "close" (USSR/Russia) and "distant" (U.S.) countries alternately for the sake of its own national goals, taking into account internal and external factors (Kissinger, 2012, pp.57-77, 83-86). Russia occupies a significant place in China's current diplomacy as evidenced by the fact that it is the only country designated as a "global strategic partner" of China and its actual ally in the global confrontation with the United States.

Relations with the U.S. have had a special, if not exceptional, place in China's diplomacy for the past forty years. The paradigm of their development was laid down personally by Deng Xiaoping. For example, Niu Jun writes: "Deng Xiaoping believed that the Chinese modernization, in the context of Chinese-American relations, was the main external factor closely connected with the prosperity of the country" (Niu, 2014, p.88). According to Yuan Peng, "without Sino- 
American normalization, there would be no multilateral reforms and the policy of openness. The normalization of bilateral relations has influenced the situation in China and beyond, and this influence is felt strongly in the domestic, political, economic, and social life in China. This trajectory can be traced up to this day" (Yuan, 2015, pp.4-5). This "voluntary" dependence on the United States and the desire not to spoil relations with it have lately exposed an obvious methodological weakness and strategic miscalculation of Chinese diplomacy, which did not happen to be quite prepared for Trump's assertive "trade and sanctions" diplomacy. No matter how the "wars" with the United States end, China will need years to replace the U.S. in its foreign policy and diplomacy, and redirect the "America-bound" foreign trade to other regions of the world.

One of the features of China's current diplomacy is the global nature of its partnership strategy, covering the entire world political and economic space (discussed in detail earlier, see Grachikov, 2019a, pp.83-93). A new trait of China's diplomacy over the past five years is the clear intention to change its status in global governance from a norm-taker to a norm-maker (Lu and Bao, 2019, pp.74-106; Reilly, 2011, pp.103-136). See Table 1 for more details.

Table 1. Xi Jinping's Great Power Diplomacy in Global Governance

\begin{tabular}{|l|l|}
\hline \multicolumn{1}{|c|}{ AREA } & \multicolumn{1}{c|}{ DESCRIPTION } \\
\hline PHILOSOPHY/IDEOLOGY & $\begin{array}{l}\text { COMMUNITY OF COMMON DESTINY; CHINESE } \\
\text { DREAM; "ACHIEVING RESULTS" (you sUO Zuo wei) }\end{array}$ \\
\hline GEOECONOMICS/ GEOPOLITICS & $\begin{array}{l}\text { ONE BELT ONE ROAD INITIATIVE; CHINA-AFRICA, } \\
\text { CHINA-LATIN AMERICA, 16 (Central and Eastern } \\
\text { EUrOpe) + 1 (CHINA), ASEAN + 1 (CHINA) FORUMS }\end{array}$ \\
\hline GLOBAL ECONOMIC GOVERNANCE & $\begin{array}{l}\text { ASIAN INFRASTRUCTURE INVESTMENT BANK } \\
\text { (headquartered in Beijing), NEW BRICS DEVELOPMENT } \\
\text { BANK (based in Shanghai); G2O AS THE MAIN } \\
\text { MECHANISM WITH CHINESE PARTICIPATION }\end{array}$ \\
\hline DIPOMACY & $\begin{array}{l}\text { A NEW TYPE OF RELATIONS WITH GREAT POWERS; } \\
\text { PERIPHERAL DIPLOMACY; GLOBAL PARTNERSHIP } \\
\text { NETWORK }\end{array}$ \\
\hline
\end{tabular}

Note: compiled by the author on the basis of Xi Jinping's works (Xi, 2014). 


\section{CHINA'S IDEOLOGY IN GLOBAL GOVERNANCE}

Chinese academic discourse attaches great significance to global governance and China's role in it. Ye Wenying and Yu Longhai have noted in their study that global governance is not only a new theory with a broad connotation, but also an objective historical process of world development. In their opinion, global governance can effectively respond to global challenges, but at the same time the global governance system itself is based on principles that were engendered mainly by Western countries, and therefore does not always take into account the interests and needs of a large number of developing nations. Since China becomes increasingly involved in world affairs, it needs its own understanding and interpretation of global governance (Ye and $\mathrm{Yu}, 2014$ ).

In the mid-2000s, China started to gradually build its own ideology of global governance. Speaking at an Asian-African summit in Jakarta on April 22, 2005, President Hu Jintao for the first time proposed the idea of "building a harmonious world" - an ideological presentation of China in the field of global governance, prepared by the ideological and propaganda structures of the Chinese Communist Party and announced by its leader. It contains the following main components. The concept of harmonious security for the maintenance of peace and security is a prerequisite for the development of any country, because only by strengthening exchanges and cooperation can all countries achieve common development. The concept of harmonious security emphasizes peaceful settlement of international disputes or conflicts through consultations and negotiations within the UN framework, and opposes the violation of the sovereignty of other countries, forced interference in their internal affairs, and the use of force or threat of force.

The concept of harmonious development was put forward by $\mathrm{Hu}$ Jintao in his speech at Yale University in the U.S., where he noted that the construction of a harmonious world should be geared towards ensuring the harmonious development of the global economy. Countries should pay attention and take effective measures to promote economic globalization in a balanced, comprehensive and win-win manner and seek facilitation. Economic development, eradication 
of poverty, and regional and global economic cooperation should be actively promoted in order to jointly address global economic development problems and ensure economic security.

The concept of harmonious culture promotes interpenetration of different cultures and beliefs, as well as mutual study of various social systems and development models in order to contribute to mutual understanding among nations.

The concept of harmonious governance implies coordination of individual states and the world as a whole, coordination of relations between states and society, as well as coordination between people and nature. These types of coordination are important for building a "harmonious world."

So a "harmonious world" constitutes China's vision of global governance, which reflects traditional Chinese values in relation to the surrounding world, has realistic and objective requirements, is the logical result of the expanding Chinese influence, and represents a completely new ideology of global governance. The "harmonious peace" concept was proposed by China in response to global development trends (Guo, 2010).

In 2012, Chinese President Xi Jinping put forward a new concept called a "Community of Common Destiny", which is based on interdependent relations between countries driven by a wave of economic globalization. According to this concept, when confronted with difficulties, states take joint measures, following common interests, in order to improve common well-being and effective shared use of resources (Hao, Zhou, 2017, p.2). Dan Wenhua and Wang Peng emphasize that in 2015 China achieved significant results in diplomacy and global governance, as well as in building a "Community of Common Destiny." While 2014 is considered the "first year" when China began to participate in global governance, 2015 is the "first year of practical work" when it actively promoted its vision of global governance and achieved its first results. In 2015, China proposed a "new type" of international relations within the framework of the "Community of Common Destiny" concept. Along with a "harmonious world," a "Community of Common Destiny" is part of China's ideology 
of global governance, it matches the Chinese "way" of openness and mutual benefit, promotes cooperation and creates mutually beneficial conditions for it, and helps achieve inclusive development in all countries. The concept is based on economic cooperation between the countries participating in the One Belt One Road Initiative (Xi, 2017, pp.521-537).

\section{JINPING'S LOGIC IN GLOBAL GOVERNANCE}

China is just beginning to formulate its approach to global governance. President Xi Jinping first mentioned the need to "increase the country's global governance abilities" on September 27, 2016, when he spoke about the diplomacy of a great power with Chinese characteristics. He named several problems. Firstly, the configuration of global governance depends on the balance of power in the international arena, and so China must actively participate in global governance and make more international commitments. Secondly, more and more "gaps" become evident in global governance, and the international community is calling for its transformation. Thirdly, the main platform for global economic governance is the Group of 20, but it must be transformed into a long-term governance mechanism. Fourthly, Xi Jinping named global governance mechanisms that concerned mainly the Asian region, which is important for China: the Shanghai Cooperation Organization, the Conference on Interaction and Confidence-Building Measures in Asia, the East Asia Summit, and the ASEAN Regional Forum. Perhaps, Xi Jinping's most important call was addressed to Chinese diplomats. He urged them to enhance the country's ability to participate in global governance, and develop rules and set the agenda for it (Xi, 2017, pp.448-452).

\section{From Rules to Orders: The Logic of International Institutional Competition}

In China, international institutional competition is becoming an ever more important phenomenon with significant changes in the nature of the international system. Both leading countries and ordinary members of international institutions try to achieve their 
goals concerning strength, interests or values by creating institutions or working in them, which makes international institutional competition increasingly manifest both at the global and regional levels on a variety of agendas. There are several forms of international institutions which are involved in institutional competition from the lowest to the highest level and which can be divided into four models/dimensions: international competition of rules, international competition of regimes, international competition of organizations, and international competition of orders. International institutional competition rests on the competition of international rules ( $\mathrm{Li}$ and Luo, 2019, pp.28-57).

As a growing financial power and a recognized financial hegemon, China and the United States, respectively, are the most important players in international financial diplomacy. The global financial crisis of 2008 became a turning point, and the international financial statuses of the two countries have changed significantly since then, but in opposite directions. More precisely, China is continuing to grow financially, while America's position remains relatively weak, which encourages China to pursue persistent financial diplomacy and forces America to adopt defensive financial diplomacy. The financial and diplomatic game between the two countries manifests itself in their competition for forming and dominating international financial institutions. On the one hand, China is making efforts to promote the reform of existing international financial institutions and seeking to play a leading role in establishing new institutions in order to strengthen the favorable institutional framework for its own financial growth. On the other hand, the U.S. is trying to delay or even obstruct the reform of international financial institutions and undermining China's efforts to create new international institutions in order to maintain its financial hegemony in the world. Competition between the two countries for international financial institutions is in fact linked to the financial situation, the ability to provide international financial public goods and the legitimacy of their participation in international financial institutions. Whether their behavior becomes more agreeable or mutually exclusive will 
have a long-term impact on the overall financial situation in the world (Li Wei, 2016, pp.112-138).

The reason for this phenomenon is that the traditional concept of security and internal governance structures have not really changed and its special needs for ensuring security abroad cannot be easily converted into market demand. This gap between demand and supply in the field of security clearly indicates that China needs to reform its overall structure of overseas security and external interests (Xiao He, 2018, p.94).

So unlike classic understanding of global governance, pragmatist and strategist $\mathrm{Xi}$ Jinping understands global governance as a balance of power in the international arena and institutional competition. And this is where the fundamental difference lies. Laurent Estachy's schematic model (Fig.1) of Chinese strategy and Chinese vision of global governance reflects the Chinese approach.

Fig 1. China's Grand Strategy

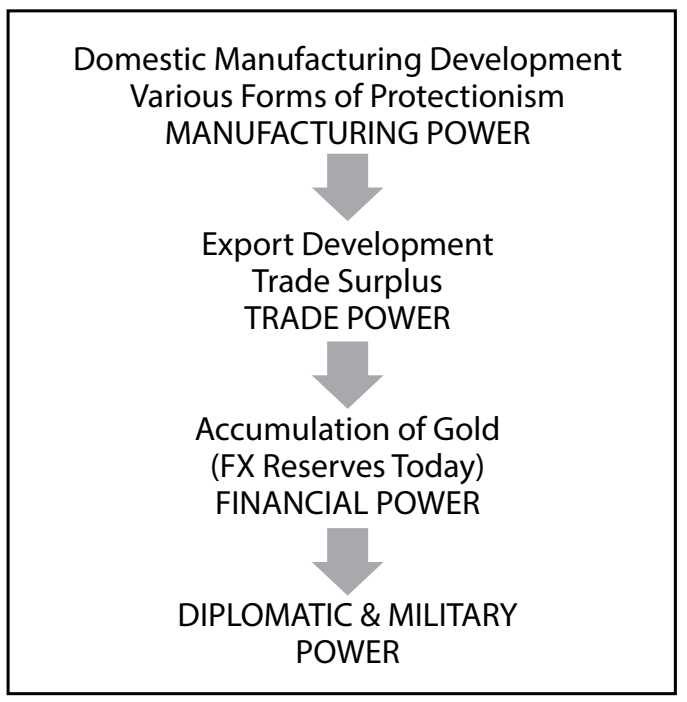

Source: Estachy, Laurent, 2020. Power Struggle between China and the United States. Vestnik MGIMO-University, 13(1), pp.82-99. 
Table 2. Chinese Vision of Global Governance

\begin{tabular}{|c|c|}
\hline $\begin{array}{l}\text { Types } \\
\text { of Global } \\
\text { Governance }\end{array}$ & Authors/Articles \\
\hline $\begin{array}{l}\text { Global } \\
\text { Economic } \\
\text { and Financial } \\
\text { Governance }\end{array}$ & $\begin{array}{l}\text { Cai Feng, 2019; Hang and Yang Lize, 2019; Zhang Falin, 2019; Pang Xun, } \\
\text { 2017; Cong Xiaonan, 2017; Luo Li Xiangyang, 2014; Xu Bin, 2013; Liu } \\
\text { Junhong, 2010; Qiang Jianxin, 2010; Tang Yongsheng, } 2010\end{array}$ \\
\hline UN Reform & Research Group of CICIR, 2015; Zhang Guihong, Guo Fenchen, 2014 \\
\hline $\begin{array}{l}\text { International } \\
\text { Order }\end{array}$ & $\begin{array}{l}\text { Qin Yaqing, 2019; ; Li Wei and Luo Yifu, 2019; Wang Hui, 2018; Su Changhe, } \\
\text { 2017; Zhang Shenjun, 2017; Gao Qiqi, 2015; Qin Yaqing, 2014; Zhang } \\
\text { Ming, 2013; Wang Sheng \&Luo Xiao, 2013; Chen Zhimin, } 2013\end{array}$ \\
\hline G20 & Xiang Nanyue and Liu Hongsong, 2017; Wang Ying \& Li Jiguang, 2012 \\
\hline $\begin{array}{l}\text { The Changing } \\
\text { Identity of China }\end{array}$ & Chen Yue, 2018; Wu Zelin, 2017; Zhao Yang, 2016; Niu Xinchun, 2015. \\
\hline $\begin{array}{l}\text { Global Climate } \\
\text { Governance }\end{array}$ & Li Huiming, 2017; Kang Xiao, 2016; Bo Yan and Gao Xiang, 2014 \\
\hline $\begin{array}{l}\text { International } \\
\text { Security } \\
\text { Governance }\end{array}$ & Xiao He, 2018; Zhang Chun, 2016 \\
\hline $\begin{array}{l}\text { Global } \\
\text { Cyberspace } \\
\text { Governance }\end{array}$ & $\begin{array}{l}\text { Li Yan, 2019; Guo Xiaobing, 2018; Lu Chuanying, 2016; Wang Mingguuo, } \\
\text { 2015; Ren Lin, 2013; Yi Wenli, } 2012\end{array}$ \\
\hline $\begin{array}{l}\text { Global } \\
\text { Investment } \\
\text { Governance }\end{array}$ & Zhang Xiaoning, 2016 \\
\hline $\begin{array}{l}\text { China-U.S. } \\
\text { Relations }\end{array}$ & $\begin{array}{l}\text { Lu Lingyu and Bao Jiazheng, 2019; Zhou Qi, 2019; Jia Qingguo, 2019; Ji } \\
\text { Zhiye, 2019; Sun Xuefeng and Zhang Xikun, 2019; Diao Daming, 2019; } \\
\text { Guo Xiaobing, 2018; Yu Xiang, 2018; Symposium, 2018; Xiao He, 2016; Li } \\
\text { Wei, 2016; Mo Shengkai, 2015; Yan Peng, 2015; Tu Xinquan, Su Xiao and } \\
\text { Yao Yan, } 2015\end{array}$ \\
\hline
\end{tabular}

Source: Authors' calculations

Note: Two editions of China's leading think tanks were analyzed: the journal Contemporary International Relations of the Chinese Institute of Contemporary International Relations and the journal World Economics and Politics of the Chinese Academy of Social Sciences for the period from 2010 to 2019.

As can be seen from Table 2, global economic and financial governance is the main element of the Chinese understanding of global governance, and the principal partner with whom it should negotiate is the United States. An important variable is the international order as the basis 
of global governance. Global cyberspace governance, international security governance, and global climate governance are fairly new variables. Although there is little literature on the G20, this topic is constantly raised in Chinese leaders' speeches at various levels. A completely new aspect related to global governance is the change of China's identity as "towering," "responsible," "global," "great," "a new leader changing the United States," and "the main competitor of the United States." All these connotations indicate that China is making serious and elaborate plans to replace the United States as the leader of the world political system, which offers the world its values as universal.

Donald Trump twitted out earlier this year that there was a possibility of a complete breakup between America and China. "Perhaps I didn't make myself clear, but the U.S. certainly does maintain a policy option, under various conditions, of a complete decoupling from China." U.S. Secretary of State Mike Pompeo and Director of the Central Foreign Affairs Commission of the Chinese Communist Party Yang Jiechi met in Hawaii in June of this year to discuss the fight against the coronavirus epidemic. The United States stressed the need for full transparency and information exchange to combat the ongoing pandemic.

The American leader has signed the 2020 Uighur Human Rights Policy Act, which imposes sanctions against Chinese officials for oppressing Uighurs and for violating human rights, such as the systematic use of disciplinary camps, forced labor, and intrusive supervision to destroy the ethnic identity and religious beliefs of Uighurs and other minorities in China.

Trump's move suggests that there can be no return to "normal" relations in the future-China is too sensitive to any interference in its internal affairs. The situation of Uighurs in the Xinjiang Uighur Autonomous Region has now been added to the issues of the Dalai Lama, Tibet, Taiwan, human rights, and others. Trump has perhaps erected an insurmountable "great wall" in relations with China and 
now it is not important how the trade negotiations will end, because the process of "destroying" bilateral relations has been set in motion and China will not be able to do anything about it. The struggle for global leadership in global governance has spilled into the open.

A new generation of young Chinese diplomats is abandoning the established norms in favor of aggressive approaches that promote a COVID-19 narrative beneficial to China. This is called wolf warrior diplomacy and it has unpleasant consequences. Shortly before the COVID-19 crisis erupted, Chinese Foreign Minister Wang Yi had instructed the country's diplomatic corps to adopt a more persistent approach to protecting China's interests and reputation abroad. The pandemic, which would not have been so dramatic if it had not been for the initial mistakes of the local authorities in Wuhan, provided an excellent opportunity to implement his instructions. And this is exactly what Chinese diplomats are doing. For example, in the middle of March, Zhao Lijian, the newly appointed Foreign Ministry deputy spokesperson, came up with a conspiracy theory by claiming that the U.S. military had delivered the new coronavirus to Wuhan, the first epicenter of the pandemic. Similarly, in early April, the Chinese Ambassador to France posted a series of anonymous articles on his Embassy's website alleging that elderly victims of the virus had been left alone to die in the country. Later that month, after Australia had joined the United States in calling for an international investigation into the origin of the pandemic, China's Ambassador in Canberra immediately threatened boycotts and sanctions against Australia (Pei, 2020).

There are a number of ways to fill the global governance gap:

- To carry out gradual reform of the existing system of global governance;

- To use the leading role of the UN and expanding the power of its structures in global governance;

- To create G20 governance mechanisms;

- To establish new international institutions like the Asian Infrastructure Investment Bank created by China and widely supported by developing countries; 
- To take into account the role of non-state actors and networks in filling global governance gaps.

Modern China is not only an active participant in global governance, but it is also one of its main beneficiaries and even a leader to some extent. As the main "troublemaker" and the reformer of the existing system of international relations and its global institutions, China should continue to contribute to the transformation of these institutions, especially international financial organizations and the multilateral trading system. Global governance reform should affect not only administrative aspects by increasing the effectiveness of international organizations, but also political ones by promoting democratization and the legitimization of global international organizations.

\section{References}

Bo Yan and Gao Xiang, 2014. The Transformation of Global Climate Change Regime. World Economics and Politics, No. 2, pp.48-65.

Cai Feng, 2019. Globalization, Convergence, and China's Economic Development. World Economics and Politics, No. 3, pp.4-18.

Chen Zhimin, 2013. Governance Models of a Multipolar World. World Economics and Politics, No. 10, pp.4-23.

Cong Xiaonan. 2017. Potential Influence of the Northwest Passage on Global Economics and China's Countermeasures: Based on Global Multi-Regional CGE Model. World Economics and Politics, No. 2, pp. 106-129.

Chen Yue, 2018. The Changing Identity of China in Global Governance and International Institutions. Contemporary International Relations, Vol. 28, No. 5, pp.105-116.

Diao Daming, 2019. Trump Administration's Foreign Policy: Structure, Causes and Impacts. Contemporary International Relations, Vol. 29, No. 5, pp.95-106.

Diplomatic Strategies, 2020. Waijiao zhanlue [Diplomatic Strategies]. BaikeBaidu [Chinese Segment] [online]. Available at: <http://baike.baidu.com/it em/\%E5\%A4\%96\%E4\%BA\%A4\%E6\%88\%98\%E7\%95\%A5> [Accessed 20 November 2020]. 
Gao Qiqi, 2015. Global Co-Governance: The Difference of World Order Between China and the West and Its Reconciliation. World Economics and Politics, No. 4, pp.67- 87.

Global Governance, 2015. V.G. Baranovsky and N.I. Ivanova (eds.) Global'noye upravlenie: vozmozhnosti i riski [Global Governance: Opportunities and Risks]. Moscow: IMEMO: RAN

Grachikov, E., 2015. Osobennosti vneshnej politiki Kitaya: etapy smeny strategiy [China's Foreign Policy: Stages of Changing Strategies]. Obozrevatel' [Observer], No. 3 (202), pp.34-46.

Grachikov, E., 2019a. Strategiya partnyorskih otnoshenī̄ KNR: praktika i yeyo kontseptualizatsiya (1993-2018) [Chinese partnership strategy: practice and its conceptualization (1993-2018)]. Mirovaya ekonomika i mezhdunarodnye otnosheniya [World Economy and International Relations], 63(3). DOI:10.20542/0131-2227-2019-63-3-83-93

Grachikov, E., 2019b. Chinese School of International Relations: How Theory Creates Diplomatic Strategy and Vice Versa. Russia in Global Affairs, Vol. 17, No. 2. Available at: <https://eng.globalaffairs.ru/articles/chinese-school-ofinternational-relations/> [Accessed 20 November 2020].

Grachikov, E., 2019c. Stanovlenie kitayskoi shkoly mezhdunarodnyh otnosheniy: analiticheskie podhody i metody issledovaniy. Vestnik RUDN. Seriya: Mezhdunarodnye otnosheniya [Formation of the Chinese School of International Relations: Analytical Approaches and Research Methods]. Vestnik RUDN. Mezhdunarodnye otnosheniya [International Relations], 19 (2). DOI: 10.22363/2313-0660-2019-19-2- 187-200.

Huang Rihan and Yao Yufei (eds), 2013. Guoji guanxi shiyong shouce/Huang Rihan, Yao Yufei zhubian [Practical Handbook of International Relations]. Tianjin: Tianjin People's Publishing House.

Guo Zhenyuan (ed.), 2010. Jianshe hexie shijie: lilun yu shijian. Beijing: Shiji zhishi chubanshe [Building a Harmonious World: Theory and Practice]. Beijing: World Knowledge Press.

Jia Qingguo, 2019. How to Understand the Current Sino-U.S. Relationship. Contemporary International Relations, Vol. 29, No. 2, pp.34-47.

Ji Zhiye, 2019. Shifting Great Power Relations: Toward Consideration of U.S. Hegemony. Contemporary International Relations, Vol. 29, No. 2, pp.10-16.

Jin, Canrong and $\mathrm{Gu}$, Mingming, 2016. Re huati yu leng sikao - guanyu ershi guo jituan yu quanqiu zhili zhong de zhongguo juese de duihua te yao zhuanjia 
[Hot Topics and Cold Thoughts - A Dialogue on the G20 and the Chinese Role in Global Governance]. Dangdai shijie yu shehui zhuyi [Contemporary World and Socialism], 4.

Jin Zhengkun, 1999. Xiangdai waijiaoxue gailun. Zhongguo renmin daxue chubanshe [Introduction to Contemporary Diplomacy]. Beijing: China People's University Press, pp. 87-90.

Hong Bing, 1999. Guojia liyi lun. Beijing: Junshi kexue chubanshe [Hong Bing. Theory of National Interests]. Beijing: Military Science Press.

Kang Xiao, 2016. Diversity and Coexistence: Creation of the View of Global Governance in Sino-U.S. Climate Cooperation. World Economics and Politics, No. 7, pp. 34-57.

Kissinger, Henry, 2012. On China. Penguin Books, pp. 57-77, 83-86.

Liu, Junhong, 2010. Globalization and the Reform of the International Financial and Monetary Systems. Contemporary International Relations, Vol. 20. No. 5, pp.73-88.

Li Huiming, 2017. Global Climate Governance Influences International Order Transition and Reconstruction: Mechanism and Path. World Economics and Politics, No. 3, pp.62-84.

Li Xiangyang, 2014. The Global Economic Order. Contemporary International Relations, Vol. 24, No. 4, pp.43-47.

Li Wei and Luo Yifu, 2019. From Rules to Orders: The Logic of International Institutional Competition. World Economics and Politics, Vol. 4, pp.28-57.

Li Wei, 2016. Sino-U.S. Diplomatic Competition in International Financial Institutions. World Economics and Politics, No. 4, pp.112-138.

Li Yan, 2019. Global Cyberspace Governance: State Actors and the ChinaUS Cyber Relationship. Contemporary International Relations, Vol. 29, No. 2, pp.105-124.

Lu Chuanying, 2016. Cyberspace Global Governance and Multi-Stakeholder Theory. Beijing: Current Events Publishing House.

Lu Lingyu and Bao Jiazheng, 2019. Cong zhizaozhe dao soquzhe: baquan shuailuo de luoji. "Shijie jingji yu zhengzhi" [Lu Lingyu and Bao Jiazheng. From Maker to Taker: A Logic of Hegemonic Decline.] World Economics and Politics, No. 9, pp.74-106.

Luo Hang and Yang Lize, 2019. Balance of Power and Decision-Making Efficiency in International Organizations: A Case Analysis of BRICS New 
Development Bank and Contingency Reserve Arrangement. World Economics and Politics, No. 2, pp.123-154.

Mo Shengkai, 2015. Power Transition and Preventive Cooperation: The Path to China-U.S. New Relation from Perspective of Processual Constructivism. World Economics and Politics, No. 2, pp.16-40.

Niu Jun, 2014. "Lianmeng yu zhanzheng": lengzhan shiqi de Zhongguo zhanlue juece ji houguo. "Shijie jingji yu zhengzhi" [Niu Jun. "Alliances and Wars": Chinese Strategic Policy and Its Results during Cold War]. World Economics and Politics, No. 6, p. 88.

Niu Xinchun, 2015. On China’s International Identity: A Horizontal Analysis. Contemporary International Relations, Vol. 25, No.1, pp.39-55.

Pang Xun, 2017. Selective Failure of Indicator Power in Global Governance: A Case Analysis of the IEG Aid Effectiveness Ratings. World Economics and Politics, No. 11, pp.130-155.

Pang, Zhongying, 2016. Zhongguo zai jiejue quanqiu zhili chizi zhong de zuoyong [Global governance deficit and its solution: China's role]. Shehui kexue [Social Science], 12.

Pei, Minxin, 2020. China's 'Wolf Warrior’ Diplomats Are Being More Reckless than Donald Trump. That's a Mistake. South China Morning Post, 13 June.

Qin Yaqing (ed.), 2014. World Politics and Global Governance: Essays on International Relations. Beijing: World Knowledge Press.

Qin Yaqing, 2019. Global Governance: Rebuilding of Order in a Multiplex World. Beijing: World Knowledge Press.

Qiang Jianxin, 2010. The International Monetary System and the Global Financial Crisis. Contemporary International Relations, Vol. 20, No. 5, pp.110-118.

Reilly, James, 2011. A Norm-Taker or a Norm-Maker: China's ODA in Southeast Asia. Contemporary International Relations, Vol. 21, No. 3, pp.103-136.

Research Group of CICIR, 2015. UN Reform and the Future of Global Governance. Contemporary International Relations, Vol. 25, No. 6, pp.1-13.

Ren Lin, 2013. Multi-Dimensional Power and Cyber Security Governance. World Economics and Politics, No. 10, pp. 38-57.

Su Changhe, 2017. Order and Governance in a Connectivity World. World Economics and Politics, No. 2, pp. 25-35. 
Sun Xuefeng and Zhang Xikun, 2019. China and U.S. Strategic Choices and China's Relations with Its Neighbors. Contemporary International Relations, Vol. 29, No. 5, pp.36-46.

Symposium, 2018. Are China and the U.S. Entering a New Cold War? Contemporary International Relations, Vol. 28, No. 6, pp.1-13.

Tang Yongsheng, 2010. The Global Expansion of Capital Logic. Contemporary International Relations, Vol. 20, No. 1, pp.39-43.

Tu Xinquan, Su Xiao and Yao Yan, 2015. American Hegemony Decline and the Doha Dilemma - Analysis Based on the Theory of Structural Power. Contemporary International Relations, Vol. 25, No. 6, pp.100-113.

Wang Sheng and Luo Xiao, 2013. Changes in the International Order and China's Regional Diplomacy. Contemporary International Relations, Vol. 23, No. 6, pp.19-36.

Wang Hui, 2018. Challenges to the International Nuclear Order. Contemporary International Relations, Vol. 28, No. 6, pp.102-122.

Wang Mingguo, 2015. Global Internet Governance: Model Change, Institutional Logic and Path Reconstruction. World Economics and Politics, No. 3, pp.47-73. Wang Ying and Li Jiguang, 2012. China and G20. Contemporary International Relations, Vol. 22, No. 4, pp.1-14.

Wu Zelin, 2017. China’s Global Connectivity Capacity in a Connectivity World. World Economics and Politics, No. 11, pp. 35-64.

Xi Jinping, 2014. The Governance of China. Beijing: Foreign Languages Press.

Xi Jinping, 2017. The Governance of China. Vol. 2. Beijing: Foreign Languages Press.

Xiao He, 2018. International Security Governance and Protection of Chinese Overseas Interests. World Economics and Politics, No. 1, pp.94-116.

Xiao He. 2016. Typology of Relations Between Hegemons and Other Great Powers. World Economics and Politics, No. 3, pp.44-73.

Xiang Nanyue and Liu Hongsong. 2017. Analyzing the Effectiveness of the G20's Cooperative Governance Model. World Economics and Politics, No. 6, pp.122-147.

Xu Bin, 2013. Market Failure, Institution Design and Global Energy Governance. World Economics and Politics, No. 11, pp.78-95. 
Xu Jia, 2006. Lun liyi bianjie yu bentu bianjie guanxi [The Relationship Between the Borders of Interests and State's Borders]. In: Xu Jia (ed.). Zhongguo guojia liyi yu yingxiang [China's National Interests and its Influence]. Beijing: Current Affairs Press, p.19.

Yan Xuetong, 1996. Zhongguo guojia liyi fenxi. Tianjin renmin chubanshe [Analysis of China's National Interests]. Tianjin People's Press.

Yang Hao, 2013. A Summary of the First National Forum on Global Studies and Global Governance. World Economics and Politics, No.7, pp.63-64.

Yuan Peng. 2015. A New Model of China-U.S. Relations after China's Second Reform. Contemporary International Relations, Vol. 25 No. 1, pp. 1-17.

Ye Xiaodi, 2019. Rediscovering the Transition in China's National Interest: A Neoclassical Realist Approach. Journal of Current Chinese Affairs, Vol. 48 (1), pp.76-115.

Ye Zicheng, 2003. Zhongguo da zhanlue [The Grand Strategy of China]. Beijing: China Social Science Press.

Yi Wenli, 2012. Divergence and Cooperation between China and the U.S. on Cyberspace. Contemporary International Relations, Vol. 22, No. 4, pp.124-141.

Yu Xiang, 2018. China-U.S. Trade War and Its Future. Contemporary International Relations, Vol. 28, No. 5, pp.55-65.

Yuan Peng, 2013. China's Grand Strategy Seen from the Report to the CPC 18th National Congress. Contemporary International Relations, Vol. 23, No. 4 July/ August, p.3.

Zhang Falin, 2019. The Chinese Effects on Global Monetary Governance. World Economics and Politics, No. 8, pp.96-126.

Zhang Ming. 2013. Global Commons: From Partial Governance to Global Governance. World Economics and Politics, No. 11, pp.57-77.

Zhang Yuyan (ed.), 2016. China and Globalization: View from Beijing and Moscow. Beijing: Chinese Social Science Press.

Zhang Shenjun, 2017. A New Paradigm of "South-Easternism" in Global Governance. World Economics and Politics, No. 5, pp.4-20.

Zhang, Lin, 2016. Lun zhongguo zai G20 kuangia xia de quanqiu zhili - jiyu Hangzhou fenghui yu lujie G20 fenghui de duibi [China's Global Governance under the G20 Framework. Based on the Comparison between Hangzhou Summit and Previous G20 Summits]. Qianyan lilun [Frontier Theory], Vol. 39, p.906. 
Zhang Chun, 2016. Current Development of Security Privatization and Implications for International Politics. World Economics and Politics, No. 6, pp.4-21.

Zhang Guihong and Guo Fenchen (eds.), 2014. China, the United Nations and Global Governance. Beijing: World Knowledge Press.

Zhang Lihua (ed.), 2015. Introduction to International Organization. Beijing: Science Press.

Zhang Xiaoning, 2016. A Path to New Global Investment Governance: Implications of the G20 Guiding Principles for Global Investment Policymaking. World Economics and Politics, No. 10, pp.4-18.

Zhao Yang, 2016. Temporal Construction of China's Identity as a "Responsible Power". World Economics and Politics, No. 7, pp.108-130.

Zhou Qi. 2019. Trump's China Policy and Its Decision-Making Environment. World Economics and Politics, No. 3, pp.57-78.

Zou Yabao and Wang Kai, 2011. Lun G20 jizhi hua ji zhongguo zai quanqiu jingji zhili zhong de celüe [Institutionalization of G20 and China's Strategy in Global Economic Governance]. Guoji jingji zhanlue [International Economic Strategy], Vol. 2, No. 6.

Guo Xiaobing, 2018. The Origin, Obstacles and Prospects of Sino-US Space Cooperation. Contemporary International Relations, Vol. 28, No. 6, pp.123-134. 